\title{
Hybridity in Giallo: The Fruitful Marriage Between Italian Crime Fiction and Theatre, Literary Geographies, and Historical and LiteraRY FICTION
}

\section{Brigid Maher and Barbara Pezzotti}

This special issue is devoted to the analysis of hybridization in crime fiction. According to David Duff, generic hybridization is "[ $t$ ] he process by which two or more genres combine to form a new genre or subgenre; or by which elements of two or more genres are combined in a single work" (Duff, "Key Concepts" xiv). This broad definition captures quite neatly the forms of overt experimentation with genre conventions often considered characteristic of contemporary literature (Hassan 170) and other art forms. For Jutta Ernst, the term "hybrid genres" denotes literary forms that unite characteristics of different genres and that, because they explode conventional genre typologies, cannot adequately be described with the genre designations used in the Western literary tradition (267).

In the last few decades, many scholars have explored hybridization in literature. Both Christin Galster (15) and Klaudia Seibel (137) begin their studies of literary hybrids by stressing the distinctness and heterogeneity of the literary classes as a precondition for the formation of hybrids; some scholars prefer to use the terms "blurring" (Hutcheon 9) or "dissolution" of genre boundaries (Duff, "Introduction" 16). Finally, very recently Martina Allen has supported the use of "conceptual blending" as opposed to "genre mixing" for indicating the creation of dynamic conceptual structures constructed for specific purposes and according to specific situations (Allen 12). In any case, analyzing contemporary literature, Ansgar Nünning sees a "proliferation of hybrid genres" which integrate factual material into fictional narratives such as "the New Journalism" and the "non-fiction novels," "historiographic metafiction," "documentary fiction," a revisionist type of "postmodernist historical novel," "uchronian fantasy," "parahistorical novels," and "factifiction" (282). More dramatically, Fishelov declares that "hybridization in literature is $[\ldots]$ more common than hybridization in nature" (20). All these views imply that literature has a dynamic nature that allows such blurring or dissolution. 
What about crime fiction specifically? For a long time, scholars have emphasized the supposedly fixed and formulaic structure of the crime narrative. ${ }^{1}$ In particular, for Tzvetan Todorov, while "the literary masterpiece does not enter into any genre save perhaps its own, [...] [d] etective fiction has its norms; to 'develop' them is also to disappoint them: to 'improve upon' detective fiction is to write 'literature', not detective fiction” (43). In other words, in Todorov's view, crime fiction ceases to be such if any improvement or change to its rigid structure is made. Eco also stresses that crime fiction is a formulaic genre: "from the beginning the reading of a traditional detective story presumes the enjoyment of following a scheme." Moreover, we are "dealing [not] only with a schematism in the order of a 'plot', but with a fixed schematism involving the same sentiments and the same psychological attitudes" (117-18). Finally, Cawelti insists on the conservative nature of crime fiction, underlining the idea that the "pleasure and effectiveness of [...] formulaic work depends on the intensification of a familiar experience." This establishes "a world with which we become familiar by repetition" (10). All these interpretations seem to preclude change or evolution in a repetitive genre. However, the history of crime fiction, which has experienced a proliferation of subgenres such as the hard-boiled novel or the police procedural, and the success of the historical crime novel and true crime stories, seems to disprove this. Some more recent scholarship acknowledges the presence of progression and change in crime fiction. For example, Collins and Neale argue that crime fiction is a genre that does not have enduring norms, but continually reworks or transforms its own conventions. Heta Pyrhöen points out that as a dynamic process, the crime genre is dominated by repetition, but also fundamentally marked by difference and evolution. Even more interestingly, John Scaggs has argued that "since one of the defining characteristics of crime fiction is its generic (and subgeneric) flexibility and porosity" (2), the genre is also open to hybridization. Luigi Cazzato explains that in crime fiction and science fiction, hybridization is in fact a way to recuperate and "rehabilitate" elements such as a story, plot, and characters that had been neglected by postmodern experimentalism (15-26). Finally, Jean Anderson et al. argue that the appeal of crime series in particular lies in a constant tension between repetition and innovation.

In Italian bookstores, the section devoted to crime fiction is constantly expanding to accommodate the increasing number of authors practising in all the

\footnotetext{
${ }^{1}$ See Arnaud, Lacassin, and Tortel; Todorov (42-52); Eco ("Narrative Structures" $144-72$ and The Limits 85-87); and Sciascia (216-31).
} 
sub-genres, from the whodunit to "the angst-ridden noir to the hyper-technical 'procedural' and the exotic historical mystery" (Somigli 7). As well as conquering Italian and international readerships, ${ }^{2}$ Italian crime fiction has also become the object of lively scholarship in the last few decades. Among other scholars, Giuseppe Petronio argues that like international crime fiction, the giallo is "vischioso" and constantly changing (188). ${ }^{3}$ Stefano Tani argues that in Italy a hybridization between the so-called letteratura alta and crime fiction has generated the best-seller di qualità, Umberto Eco's Il nome della rosa (1980) being the most famous and successful example. Nicoletta Di Ciolla thinks that the giallo is "an effective, if hybrid, category of narrative fiction, capable of foregrounding themes and issues that are in tune with the readers' own, becoming a prime site for the articulation of concerns about society" (7). However, some scholars still highlight how literary and allegedly more "serious" authors have appropriated or extrapolated from crime fiction topoi in order to write novels that are weightier novels than a mere giallo (Barbolini). The perspective of this special issue is different: it shows that by being either the "contaminating" or the "contaminated" genre, crime fiction has been able to create meaningful literature able to deal with pressing issues in Italian society, in some cases acting as a pedagogical tool or contributing to national debates on identity, racism, or gender and sexuality in Italian society. Like crime fiction in general, Italian crime fiction first emerged from existing genres, such as the adventure novel and the feuilleton. However, it very soon crossed its original boundaries by progressively absorbing and re-interpreting themes and forms of other genres, such as travel literature and the historical novel. It has also crossed media, interacting with the language and images of cinema, journalism, the comics and theatre. Finally, it has been introduced into so-called highbrow literature, often revitalizing it.

Over the course of its history, the giallo has expanded horizontally to include small villages, big metropolitan cities, and the urban sprawl as its setting. In so

\footnotetext{
2 According to Istat, the print run of "romanzi gialli e d'avventura" increased from 15.6 million in 1996 to 21.8 million in 2001. Moreover, according to La Porta, from 1994 to 2003 the sales of crime fiction grew by 450 percent, while Italian crime fiction increased from 7 to 24 percent of the total (58-59).

${ }^{3}$ Giallo (pl. gialli) is the term commonly used for crime fiction in Italy. It means "yellow" from the color assigned to the covers of one of the first Italian series of crime fiction launched in 1929 by the publisher Mondadori. In this article, we use the term giallo in its broadest meaning - that is to say, a story where there is a crime and an investigation takes place—as commonly accepted by authoritative scholars, such as Petronio.
} 
doing, it has often served as an indicator of the transformation of the territory through urbanization, pollution, and exploitation over the past few decades. While Italian crime fiction seems to create more and more "occupied space" (Moore 123), it has also extended vertically, exploring history and its interstices. Due to its special relationship with topics such as legality, culpability, and responsibility, a crime novel is in fact a most suitable medium for recounting history (Browne and Kreiser xiv). The formula of the investigation allows authors to tackle history from a hypocaliptic perspective: that is, using a micro-story—the investigation itselfto illustrate a macro-story or history that can function as a wider investigation into a society and its times (Ginzburg 57-106). More importantly, in historical crime novels, the detective's enquiry into the past often allows crime writers to draw a parallel between the past of the investigation and the present of the reader and to comment on contemporaneous events (Milanesi 13). Apart from expanding horizontally and vertically, the giallo has successfully expanded laterally, blending with other genres such as biography, theatre, romance, literature of immigration, letteratura alta, and juvenile fiction.

The contributors to this special issue explore the above topics and genre intersections from a range of different perspectives. Marco Paoli examines the fusion of genres in Giorgio Scerbanenco's Duca Lamberti series. He looks at the ways in which the famous giallista's writing was shaped by his familiarity with the publishing industry and the workings of print media, as well by his own life experience. Daniela Cavallaro's contribution focuses on gialli for the theatre, more specifically on all-female educational plays sponsored by the Catholic Church and intended for young and impressionable performers and audiences. She observes that in these texts, written by Salesian priests and sisters, the crime-solving element of the plot was of less importance than sending a message about late-1950s gender roles in Italy.

Mirna Cicioni explores the genre intersection between biography, historical fiction, and crime fiction, looking at novels in which Pellegrino Artusi and Dante Alighieri appear as fictionalized sleuths, allowing the authors to reflect on past and present-day Italy, and on both epistemological and ontological forms of knowledge. Luciana d'Arcangeli and Laura Lori take on the relationship between giallo and post-imperial literature: through an analysis of a number of works of crime fiction dealing with the country's colonial past in Africa, they show how the genre is being used by novelists wishing to engage with a chapter in Italy's history that many consider to be under-discussed in public debates. In a comparative piece, 
Barbara Pezzotti analyzes two historical crime novels set during the Fascist era, one written in the 1990s by Carlo Lucarelli and the other two decades later by Maurizio De Giovanni, and finds two quite different representations of the period. She argues that the less critical tenor of the more recent text is also due to an overcharged hybridization of the novel (which mixes elements of the supernatural, romance, and historical fiction) and is indicative of a change in the public debate about the legacy of Fascism.

Enrichetta Frezzato analyzes crime fiction as a form of literary geography and impegno, focusing in particular on the way in which, over some twenty years, Massimo Carlotto's work has explored social, historical, and geographical questions of space in different ways, moving, ultimately, from the local to the global. The final two contributions to this special issue look at topics related to identity and social roles. Rita Wilson's case study of the work of Amara Lakhous shows how the Algerian-Italian novelist uses the hybrid genre of humorous crime fiction to explore questions of social justice and the criminalization of certain populations within Italy, challenging dominant conceptions about race, culture, and criminality. Claudia Bernardi analyzes three novels by Rossana Campo, which combine aspects of crime fiction with stories of lesbian romance and desire. She shows how Campo plays with intertextuality and genre conventions to stretch the boundaries not only of crime fiction, but also of romance fiction.

What all the diverse contributions to this issue have in common is a view of crime fiction as a genre capable of exploring important ethical, political, and social topics. The entertainment value of crime fiction makes it a particularly effective means to involve readers in important social and political discourses. Far from being a formulaic, predictable genre, crime fiction's great flexibility and vischiosità, as evidenced by the many kinds of genre contamination discussed in this collection, make it extremely well placed to investigate many issues that are important in Italian society and relate to the environment, gender, immigration, and identity, among other concerns.

\section{La Trobe University}

Australasian Centre for Italian Studies (ACIS) 


\section{Works Cited}

Allen, Martina. "Against 'Hybridity' in Genre Studies: Blending as an Alternative Approach to Generic Experimentation.” Trespassing Journal: An Online Journal of Trespassing Art, Science, and Philosophy 2 (2013).

Anderson, Jean, Carolina Miranda, and Barbara Pezzotti, eds. Serial Crime Fiction: Dying for More. London and New York: Palgrave McMillan, 2015.

Arnaud, Noël, Francis Lacassin, and Jean Tortel. Entrentiens sur la para-littérature. Paris: Pion, 1970.

Barbolini, Roberto. "Prefazione." In L'Italia in giallo. Geografia e storia del giallo italiano contemporaneo. By Massimo Carloni. Reggio Emilia: Edizioni Diabasis, 1994. 7-9.

Browne, Ray B. and Lawrence A. Kreiser The Detective as Historian: History and Art in Historical Crime Fiction. Bowling Green: Bowling Green State University Popular Press, 2000.

Cawelti, John G. Adventure, Mystery and Romance: Formula Stories as Art and Popular Culture. Chicago and London: Chicago UP, 1976.

Cazzato, Luigi. Generi, recupero, dissoluzione. L'uso del giallo e della fantascienza nella narrativa contemporanea. Fasano: Schena, 1999.

Collins, Jim. Uncommon Cultures: Popular Cultures and Postmodernism. New York and London: Routledge, 1989.

Di Ciolla, Nicoletta. Uncertain Justice: Crimes and Retribution in Contemporary Italian Crime Fiction. Newcastle: Cambridge Scholars Publishing, 2010.

Duff, David. "Introduction." In Modern Genre Theory. Ed. Duff. Harlow: Longman, 2000. 1-24.

. "Key Concepts." In Modern Genre Theory. Ed. Duff. Harlow: Longman, 2000. x-xvi.

Eco, Umberto. The Limits of Interpretation. Bloomington: Indiana UP, 1990. "Narrative Structures in Fleming." In Eco, The Role of the Reader: Explorations in the Semiotics of Texts. Bloomington: Indiana UP, 1990. 144-72.

Ernst, Jutta. "Hybride Genres." In Metzler Lexikon Literatur- und Kulturtheorie: Ansätze - Personen - Grundbegriffe. 3rd ed. Ed. Ansgar Nünning. Stuttgart: Metzler, 2004. 267-68. 
Fishelov, David. Metaphors of Genre: The Role of Analogies in Genre Theory. University Park, PA.: Pennsylvania State UP, 1993.

Galster, Christin. Hybrides Erzäblen und hybride Identität im britischen Roman der Gegenwart. Frankfurt am Main: Peter Lang, 2001.

Ginzburg, Carlo. “Spie. Radici di un paradigma indiziario.” In Crisi della ragione. Ed. Aldo Gargani. Turin: Einaudi, 1979. 57-106.

Hassan, Ihab. The Postmodern Turn: Essays in Postmodern Theory and Culture. Ohio: Ohio State UP, 1987. Hutcheon, Linda. A Poetics of Postmodernism: History, Theory, Fiction. London and New York: Routledge, 1988.

La Porta, Filippo. "Contro il Nuovo Giallo Italiano (e se avessimo trovato il genere a noi congeniale?).” In Giulio Ferroni et al. Sul banco dei cattivi. A proposito di Baricco e di altri scrittori alla moda. Rome: Donzelli Editore, 2006. $55-75$.

Milanesi, Claudio. "Le roman criminal et l'histoire. Introduction." Cahiers d'études romanes 15.1 (2006): 9-19.

Moore, Lewis D. Cracking the Hard-Boiled Detective: A Critical History from the 1920s to the Present. Jefferson, NC and London: McFarland, 2006.

Neale, Steven. "Questions of Genre.” Screen 31.1 (1990): 45-66.

Nünning, Ansgar. "Mapping the Field of Hybrid New Genres in the Contemporary Novel: A Critique of Lars Ole Sauerberg, Fact into Fiction and a Survey of Other Recent Approaches to the Relationship beween 'Fact' and 'Fiction.'” Orbis Litterarum 48.3 (1993): 281-305.

Petronio, Giuseppe. Sulle tracce del giallo. Rome: Gamberetti, 2000.

Pyrhöen, Heta. Murder from an Academic Angle: An Introduction to the Study of the Detective Narrative. Columbia, SC: Camden House, 1994.

Scaggs, John. Crime Fiction. London and New York: Routledge, 2005.

Sciascia, Leonardo. "Breve storia del romanzo poliziesco." In Sciascia, Cruciverba. Turin: Einaudi, 1983. 216-31.

Seibel, Klaudia. "Mixing Genres: Levels of Contamination and the Formation of Generic Hybrids." In Gattungstheorie und Gattungsgeschichte. Ed. Marion Gymnich, Birgit Neumann, and Ansgar Nünning. Trier: WVT Wissenschaftlicher Verlag Trier, 2007. 137-52.

Somigli, Luca. "Fighting Crimes in Times of War: Visions and Revisions of Fascism in Contemporary Detective Fiction." In Trends in Contemporary Italian Narrative 1980-2007. Ed. Gillian Ania and Ann Hallamore Caesar. Newcastle: Cambridge Scholars Publishing, 2007. 6-28. 
Tani, Stefano. The Doomed Detective: The Contribution of the Detective Novel to Postmodern American and Italian Fiction. Carbondale: South Illinois UP, 1984.

Todorov, Tzvetan. "Typology of Detective Fiction." In Todorov, The Poetics of Prose. Oxford: Blackwell, 1966. 42-52. 